\title{
The dynamics of agricultural extension delivery along the value chain: Assessment of agricultural extension activities of MMDAs in Ghana
}

\author{
S.A. MANTEAW*, B.Y. FOLITSE, J.N. ANAGLO, S. MAHAMA \& N.A. MINGLE \\ (S.A.M, B.Y.F \& N.A.M.: CSIR-Institute for Scientific \& Technological Information, \\ Accra; S.M.: Council for Scientific \& Industrial Research, Head Office, Accra; \\ J.N.A.: Department of Agricultural Extension, University of Ghana, Legon, Accra) \\ *Corresponding author's email: smanteaw@yahoo.com
}

\begin{abstract}
This paper assessed agricultural extension delivery in 216 metropolitan, municipal and district assemblies (MMDAs) in Ghana. It examined the extent of balance and the nature of extension delivery with respect to input supplying, production, processing and marketing. A survey of Heads of the Department of Agriculture in 80 MMDAs randomly selected nationwide was conducted using structured questionnaires. The data were triangulated with in-depth interview sessions with farmers, regional extension officers and private extension providers. The study showed a production-oriented nature of extension delivery across the country with $90 \%$ of respondents claiming to have focused extension delivery in their localities on production. This had led to the rather inadequate attention directed at processing and value addition on account of limited capacity of agricultural extension agents. While extension on input supplying was observed to be a private sector-driven activity in the hands of input dealers, the study showed limited extension delivery on marketing as most farmers made their own marketing arrangements. This paper makes a strong case for an extension policy that ensures a reasonable balance and one that introduces competitiveness in value chain activities. The paper also calls for sustained institutional capacity building to give providers a more balanced extension delivery.
\end{abstract}

Keywords: assessment; extension delivery; metropolitan; municipal and district assemblies; Ghana; value chain

Original scientific paper. Received 13 Oct 2020; revised 01 Dec 2020.

\section{Introduction}

Agricultural growth thrives largely on a sound, effective and efficient extension delivery system (Blumet et al., 2020; Oluwasusu \& Akanni, 2014). The justification for a central role of agricultural extension in driving agricultural development of any nation abounds in the literature (Swanson, 2008; DansoAbbeam et al., 2018). Agricultural extension has many definitions, philosophies, typologies and approaches (Gêmoet et al., 2005); however, opinions on extension have changed over the years. Emphasis has shifted from the transfer and exchange of practical production information to farmers (Rivera \& Qamar, 2003) through to helping farmers organise themselves (Shepherd, 2007). According to Sulaiman and Hall (2002), agricultural extension is designed towards supporting and strengthening farmer organisations; linking 
farmers to markets, while Swanson (2009) and USAID (2004) also viewed agricultural extension as empowering farmers and the rural poor. Equally, Farrington et al. (2002) earlier introduced the idea of developing micro-enterprises, working towards poverty alleviation and environmental conservation as aspects of agricultural extension.

The US Government's Global Hunger and Food Security Initiative, under the auspices of the United States Agency for International Development (USAID), commissioned a study into Ghana's agricultural extension delivery system in 2012. The study identified some gaps in the system, some of which was the lack of coordination at the national level in view of the sheer number of actors and organisations operating in the agricultural extension area as well as weakness in performance from the public extension services. However, one of the highlights of the findings was the fact that the mindset of much of the extension work was observed to focus on production increases, without sufficient concern for farm-level profitability, which was necessary to induce further agricultural innovations to boost productivity. Again, it was observed that extension programmes were not marketoriented. Eight years on since the USAID study, it has become necessary to explore the situation concerning agricultural extension delivery in Ghana, in an attempt to add to the body of knowledge in the subject area. This paper, consistent with Ammani and Abdullahi (2015), takes its point of departure from the assumption that agricultural extension delivery in Ghana can be strengthened to respond to its expected role as discussed in the preceding paragraphs, through the application of the value chain framework. Besides, the study conceptualises "balance" in value chain extension support services as reasonable distribution of the services along the levels of input supplying, production, processing and marketing. A skewed distribution is conceptualised as "unbalance" (FAO, 2019).

At the heart of the agricultural value chain concept is the idea of actors connected along a chain producing and delivering goods to consumers through a sequence of activities (Henriksen et al., 2010). However, this seemingly "vertical" chain cannot function in isolation. An important aspect of the value chain approach is that it also considers "horizontal" impacts on the chain, such as input and finance provision, extension support and the general enabling environment (Nguyen, 2016). According to Joshi (2015), the value chain approach has been found useful, particularly by donors, in that it has resulted in a consideration of all those factors impacting the ability of farmers to access markets profitably, leading to a broader range of chain interventions.

Given the strength of the value chain framework, there is a school of thought that suggests that the application of the value chain framework has the potential to contribute to enhancing the efficiency of agricultural extension delivery. However, there appears to be a dearth of studies in the literature regarding the application of the framework in the implementation of agricultural extension programmes in Ghana. This study, therefore, seeks to throw some clarity on this research area and add to the body of knowledge regarding the dynamics of agricultural extension delivery in Ghana within the value chain framework.

The main objective of the study was to assess the dynamics and the extent of balance in the delivery of agricultural extension along the agricultural value chain. Specifically, it sought to answer the following questions: 
i. To what extent has the delivery of agricultural extension messages along the value chain been balanced?

ii. What factors have influenced the direction of extension delivery in the various Metropolitan, Municipal and District Assemblies in Ghana?

iii. What are the dynamics of extension delivery along the various aspects of the value chain comprising input supplying, production, processing and marketing?

iv. What critical lessons can be learned to enhance the effectiveness and efficiency of extension delivery in Ghana?

\section{Material and Methods \\ Area of study}

The study was a nationwide project carried out in 10 administrative regions of Ghana. It was designed to examine the dynamics of extension delivery in 216 Metropolitan, Municipal and District Assemblies along the agricultural commodity value chain.

\section{Sampling Procedure and Data Collection}

A survey method involving interviews of Heads of the Department of Agriculture in 80 Metropolitan, Municipal and District Assemblies was employed for the study. These Heads are responsible for the implementation of agricultural extension programmes in their respective localities and thus served as the most reliable sources of primary data for the study. Furthermore, the survey data were triangulated with the results of the qualitative data.

The target population for the study was therefore the 216 Heads of the Department of Agriculture at various Metropolitan, Municipal and District Assemblies in Ghana. The choice of Heads of the Department of Agriculture was informed by the fact that they were responsible for the implementation of agricultural extension policies in their respective district, municipal and metropolitan assemblies and for that matter the sources of agricultural extension information. From a database of all the 216 Heads obtained from the Human Resource Department of the Local Government Service, simple random sampling was conducted to select 80 of the Heads for the survey using structured questionnaires. The questionnaires sought information on the direction of extension delivery along the value chain in their localities, nature of extension with regard to input supplying, production, processing, and marketing and general extension delivery in Ghana. In-depth interview sessions were held with selected individuals made up of four regional agricultural extension officers, two selected from the northern part of the country and two from the southern part; three representatives of private extension providers, one from the northern part, one from the middle part and the last from the southern part; two officials of the Directorate of Agricultural Extension at the Head Office of the Ministry of Food and Agriculture; and 10 commercial award-winning farmers, one in each of the 10 regions, purposely selected.

\section{Data Analysis}

Quantitative data from the survey were analysed using the Statistical Package for Social Sciences (SPSS) version 21. Analysis was mainly univariate with descriptive statistics (frequencies and percentages) supported by some inferential statistics (cross-tabulation, chi-square test). The qualitative data, presented in a narrative and descriptive form, were employed for the purpose of triangulation and thus helped in ensuring the general validity of the results. 


\section{Results and Discussion}

Demographic Characteristics of Survey Respondents

The respondents for the survey were largely heterogeneous as shown in Table 1, cutting across the key demographic attributes. However, in view of the rather male-dominant profile of Heads of Departments of Agriculture in the 216 Metropolitan, Municipal and District assemblies, female heads were poorly represented. The picture also portrayed an aging head of department profile with most heads $(43.8 \%)$ falling within the age bracket of above 55 years. Most of the Heads (52.5\%) had been in office from 1 to 4 years. The picture emerging from these demographic characteristics certainly has human resource implications for the implementation of agricultural programmes, and calls for a possible review of the recruitment, promotion and succession plan strategy of staff of the various Departments of Agriculture within the Metropolitan, Municipal and District assemblies.

TABLE 1

Profile of Heads of Department of Agriculture Respondents in the Survey

\begin{tabular}{lcc}
\hline Gender & Frequency & Percentage \\
\hline Male & 74 & 92.5 \\
Female & 6 & 7.5 \\
Age & & \\
$30-40$ & 1 & 1.3 \\
$41-45$ & 2 & 2.5 \\
$46-50$ & 15 & 18.8 \\
$51-55$ & 27 & 33.8 \\
Above 55 & 35 & 43.8 \\
& & \\
\hline Years of service & & \\
$1-4$ & 42 & 52.5 \\
$5-9$ & 23 & 28.8 \\
10-15 & 11 & 13.8 \\
Above 15 & 4 & 5.0 \\
\hline
\end{tabular}

Source: Fieldwork 2018

\section{Delivering Extension Messages along the} Value Chain: Extent of Balance

A major objective of the study was to examine the extent of balance in the delivery of extension messages along the commodity value chain with particular reference to input supplying, production, processing and marketing. The key highlight of the study as shown in figure 1 reflected a production-oriented nature of agricultural extension delivery at the various Metropolitan, Municipal and District Assemblies in Ghana. As many as $90 \%$ of heads of departments who participated in the survey, claimed to have focused extension delivery in their localities predominantly on production. This finding is consistent with the conclusions of Sattaka et al. (2017) that agricultural extension delivery to glutinous rice farmers was production-oriented and designed to foster production sustainability for food and cultural security of glutinous rice farmers in Vietnam.

Again, from the survey, there was little mention of extension delivery with respect to input supplying, marketing and processing, which recorded marginal figures. On the other hand, input supplying remained the least aspect of the value chain given agricultural extension attention. In-depth interview sessions with key stakeholders such as farmers and private extension providers pointed to the fact that extension on input supplying was virtually in the hand of private input supplying and agrochemical firms who target farmers in the various localities and through the sale of their products offer private extension services to clients. These private agrochemical and input supplying firms use the free offer of extension service as enticement to attract more clients to their businesses. There is no doubt their activities had complemented the 
public extension service delivery offered by the various Departments of Agriculture. This had consequently made agricultural extension delivery largely pluralist, consistent with the findings of Manteaw et al. (2015), who concluded in a study of the cocoa and pineapple value chains that private participation had generally made agricultural extension delivery more demand-driven and pluralistic.

A cross-tabulation of delivery of extension messages along the value chain across the 10 administrative regions of Ghana showed

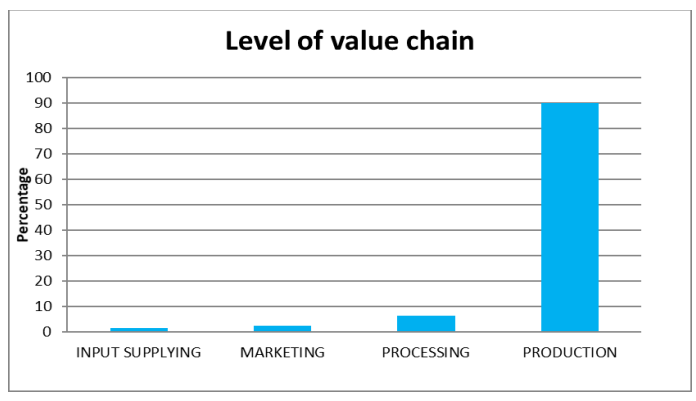

Fig. 1: Aspects of the Value Chain Given Most Extension Attention

\section{Source: Fieldwork 2018}

a similar picture of a production-oriented extension delivery nationwide.

TABLE 2

Cross Tabulation of the 10 Regions of Ghana and Most Dominant Extension Messages along the Value Chain

\begin{tabular}{|c|c|c|c|c|c|c|c|c|c|}
\hline \multicolumn{10}{|c|}{ Most Dominant Messages } \\
\hline \multirow[t]{2}{*}{ Region } & Produc & & Process & & Marke & & & & \\
\hline & Freq. & $\%$ & Freq. & $\%$ & Freq. & $\%$ & Value & $D f$ & Sig \\
\hline Upper East & 8 & 10.3 & 0 & 0.0 & 0 & 0.0 & & & \\
\hline Upper West & 5 & 6.4 & 0 & 0.0 & 0 & 0.0 & & & \\
\hline Northern & 8 & 10.3 & 0 & 0.0 & 0 & 0.0 & & & \\
\hline Brong Ahafo & 8 & 10.3 & 0 & 0.0 & 0 & 0.0 & 21.392 & 18 & 0.26 \\
\hline Ashanti & 5 & 6.4 & 1 & 1.3 & 1 & 1.3 & & & \\
\hline Western & 9 & 11.5 & 0 & 0.0 & 0 & 0.0 & & & \\
\hline Central & 9 & 11.5 & 0 & 0.0 & 0 & 0.0 & & & \\
\hline Eastern & 10 & 12.8 & 0 & 0.0 & 0 & 0.0 & & & \\
\hline Volta Region & 8 & 10.3 & 0 & 0.0 & 0 & 0.0 & & & \\
\hline Greater Accra & 8 & 10.3 & 0 & 0.0 & 0 & 0.0 & & & \\
\hline
\end{tabular}

Source: Fieldwork 2018 Alpha value* $\mathbf{p}<0.05$

Table 2 revealed that extension messages along the value chain with respect to production were delivered more in the Eastern Region $(12.8 \%)$ than the Western $(11.5 \%)$ and Central $(11.5 \%)$ regions. This was followed by Upper East (10.3\%), Northern (10.3\%), Volta $(10.3 \%)$, and Greater Accra $(10.3 \%)$. The least delivery was in the Ashanti (6.4\%) and Upper West (6.4\%) regions. A cross-tabulation test value of 21.392 (Table 2) showed that the result was not significant at alpha value of 0.05 . The implication is that delivery of extension messages with respect to production, processing and marketing was not significantly different in the 10 regions of the country.

Correspondingly, a cross-tabulation of least directed messages along the value chain across the 10 regions of Ghana in Table 3 , showed limited extension attention given to input supplying, processing and marketing. The results showed that the least attention given to input supply in the Central and Eastern Regions was 17.6 and $29.4 \%$ respectively. Furthermore, the least extension messages directed towards 
marketing recorded in the Greater Accra $(20.5 \%)$ and Western (15.4\%) were the highest. The implication is that the public extension system may be delivering limited messages on input supplying and marketing; a responsibility that may have been complemented either by farmer groups, private input dealers or private marketing organisations. Glendenning et al. (2010) indicated that the success of extension delivery either publicly or privately, depended on how it enhanced the information flow along the agricultural value chain; and whether it was done sustainably and effectively would be determined by the type of information provided, how and to whom the information was provided, the strength of the feedback in each link and the capacity of the approach to provide relevant information to all the actors involved.

TABLE 3

Cross Tabulation of the 10 Regions of Ghana and the Least Focused Extension Messages Along the Value Chain

Least Directed Messages

\begin{tabular}{lccccccccc}
\hline Region & Input supply & Processing & \multicolumn{3}{c}{ Marketing } & & \\
\hline & Freq. & $\%$ & Freq. & $\%$ & Freq. & $\%$ & Value & Df & Sig \\
\hline Upper East & 2 & 11.8 & 3 & 12.5 & 3 & 7.7 & & & \\
Upper West & 3 & 17.6 & 1 & 4.2 & 1 & 2.6 & & & \\
Northern & 1 & 5.9 & 2 & 8.3 & 5 & 12.8 & & \\
Brong Ahafo & 2 & 11.8 & 4 & 16.7 & 2 & 5.1 & 32.885 & 18 & .017 \\
Ashanti & 0 & 0.0 & 5 & 20.8 & 2 & 5.1 & & & \\
Western & 1 & 5.9 & 2 & 8.3 & 6 & 15.4 & & & \\
Central & 3 & 17.6 & 1 & 4.2 & 5 & 12.8 & & & \\
Eastern & 5 & 29.4 & 3 & 12.5 & 2 & 5.1 & & & \\
Volta Region & 0 & 0.0 & 3 & 12.5 & 5 & 12.8 & & & \\
Greater Accra & 0 & 0.0 & 0 & 0.0 & 8 & 20.5 & & \\
\hline
\end{tabular}

\section{Source: Fieldwork 2018}

Factors Influencing the Direction of Extension Delivery

The study showed that agricultural extension delivery along the value chain was largely influenced by multiplicity of factors that cut across funding, required expertise, nature of farmers' problems, prevailing levels of production and the overall objective of Departments of Agriculture of the various Metropolitan, Municipal and District assemblies. The survey of the Heads of Department of Agriculture as reflected in Table 4 , showed that there was preponderance of extension messages with regard to production on account of the fact that farmers' problems tended to focus more on production by way of husbandry practices in areas such as soil fertility management, pest and disease control. Other compelling reasons offered by survey respondents and complemented by the in-depth interview sessions for the production-oriented extension delivery included Agricultural Extension Agents' (AEAs') limited knowledge of other aspects of the value chain such as processing and the fact that production remained top on farmers' agenda with other aspects of the value chain occupying subordinate position. Mmbengwa et al. (2009) in an earlier study to examine factors that influence extension delivery identified the institutional 
capacity of extension workers as a determining factor in fashioning out the direction and effectiveness of agricultural extension. On the basis of this, they recommended the need to build the institutional capacity of extension workers in the specialised areas of production, management and marketing so that they could deliver quality services. In a more recent study, Asiedu-Darko (2013) concluded that extension agents in the Ashanti, Northern and Eastern regions of Ghana lacked the required competence to be able to deliver on their roles as agents of agricultural development. The implication is that for extension agents to have a more balanced outlook and respond equitably to all aspects of the commodity value chain, there is the need for sustained institutional capacity building.

TABLE 4

Reasons for the production-oriented extension delivery offered by Heads of Departments of Agriculture

\begin{tabular}{lcc}
\hline Reason & Frequency & Percent \\
\hline Inadequate funds to target other aspects of value chain & 5 & 6.3 \\
Other aspects such as input supplying privatised & 3 & 3.8 \\
Farmers' problems are production oriented & 33 & 40.4 \\
Limited knowledge on other aspects of the value chain & 8 & 10.0 \\
AEAs more competent in production technologies, (more capacity building of & 16 & 20.1 \\
production) & 8 & 10.0 \\
The other aspects of the value chain depend on production & 7 & 8.8 \\
One of the key objectives of the Department is to ensure food security & 80 & 100 \\
TOTAL & &
\end{tabular}

Source: Fieldwork 2018

Dynamics of Extension Delivery along the Value Chain

Extension Delivery on Production

Production of staple and industrial crops can be sustained through ready access to timely and relevant extension information. Studying the impact of agricultural extension on production, Owens et al. (2003) in a much earlier study noted that access to agricultural extension services, defined as receiving one or two visits per agricultural year, raises the value of crop production by about $15 \%$. In the current study, extension delivery on production which may have accounted for the levels of crop production and productivity was limited to providing information on cultural practices, soil and water management, disease and pest control. These areas of focus in extension delivery were noted to be of primary concern to farmers. The extension messages were mostly delivered on-farm through interaction with farmers, training and demonstrations as shown in figure 2. 


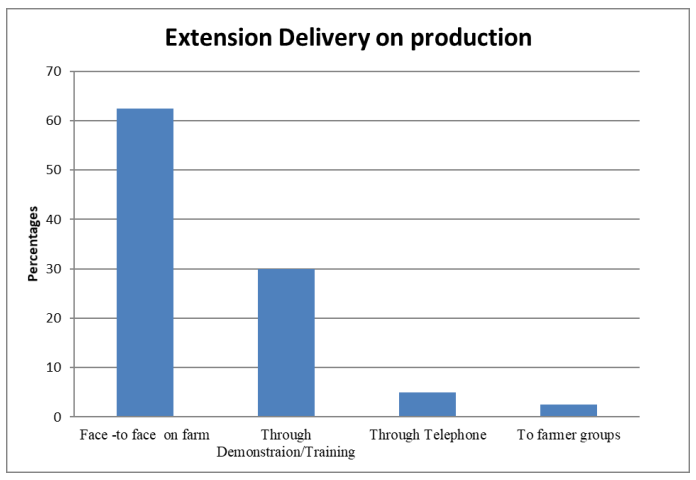

Fig. 2: Main Channels of Delivery of Extension Messages on Production

Source: Fieldwork 2018

Figure 2 showed limited use of the telephone and farmer group in extending messages despite the effectiveness of these channels. However, the face-to-face means of extension was justified on account of the AEAs extensive use of demonstration to extend technologies on farms.

Field demonstrations and training, as shown in figures 3 and 4, featured prominently on the calendar of AEAs with $97.5 \%$ and $85 \%$ of respondents claiming to have organised demonstration and training respectively in their localities within the last one year. According to Saleh et al. (2016), the training of agricultural extension workers was an integral part of the overall agricultural production process. To them, the necessary steps should be taken to identify the unfelt needs of agricultural extension workers and strengthen their knowledge, skills and attitudes required for performing their job efficiently. In support of this view, Kazeem et al. (2017), maintained that substantial rates of adoption would only be achieved if constraints to training on agricultural technology were addressed from the farmers' perspectives.

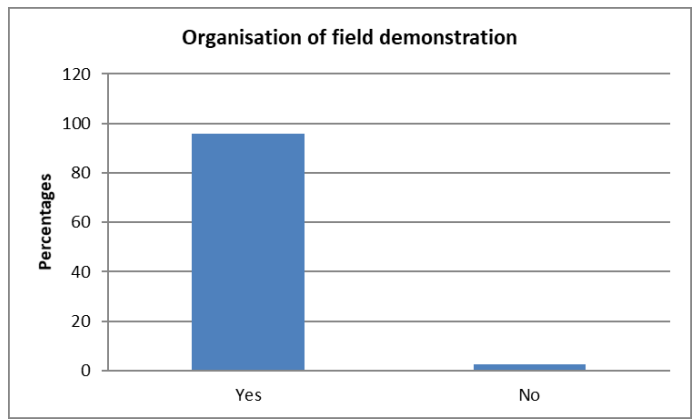

Fig. 3: Frequency of Organisation of Field Demonstration

Source: Fieldwork 2018

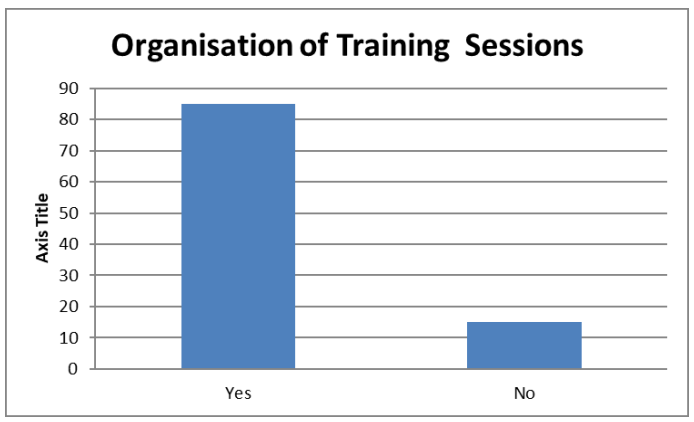

Fig. 4: Frequency of Organisation of Training Sessions

Source: Fieldwork 2018 
TABLE 5

Funding Organisations of Field Demonstrations

\begin{tabular}{lcc}
\hline Responses & Frequency & Percentage \\
\hline WAAPP & 49 & 61.3 \\
Dept. of Agric. & 10 & 12.5 \\
MMDA & & \\
MoFA (Crop & 7 & 8.8 \\
Services Dept.) & & \\
Africare & 2 & 2.5 \\
World Vision & 2 & 2.5 \\
International & & \\
IFDC & 1 & 1.3 \\
ADRA & 1 & 1.3 \\
USAID-SPRING & 1 & 1.3 \\
Presbyterian Agric & 1 & 1.3 \\
Station (GARU) & & \\
FAO & 1 & 1.3 \\
CSIR-SARI & 1 & 1.3 \\
Market-oriented & 1 & 1.3 \\
Agric. Program & & \\
(GIZ) & & 1.3 \\
ECASARD & 1 & 1.3 \\
ICRISAT & 1 & $\mathbf{1 0 0 . 0}$ \\
IITA/Africa Rising & 1 & \\
Total & $\mathbf{8 0}$ & \\
\hline Source: Fieldwork 2018 & & \\
\hline
\end{tabular}

Source: Fieldwork 2018

The issues emerging out of the study appear to confirm earlier findings by Manteaw et al. (2015), which showed more extensive use of training and demonstrations among pineapple farmers as compared with cocoa farmers leading to more innovative practices among the former. It is also instructive to note the singular contributions of the West African Agricultural
Productivity Programme (WAAPP), a 5-year sub-regional initiative funded by the World-Bank, in the promotion of most of the demonstrations as expressed by $61.3 \%$ of the survey respondents. The contributions of such development partners as the United States Agency for International Development (USAID), agricultural non-governmental organisations such as the International Fertiliser Development Centre (IFDC) and faith-based organisations such as the agricultural projects of the Presbyterian Church of Ghana at Garu in Upper East Region, Adventist Relief Agency (ADRA), Presbyterian initiated-Ecumenical Association for Sustainable Agricultural and Rural Development (ECASARD) and World Vision International, though marginal, are worth noting. Assessing the performance of such faith-based NGOs in rural development in the Nigerian State of Nasarawa. Dimelu et al. (2013) recommended greater participation of beneficiaries to evolve need/demand-oriented interventions and sustainability of programmes. To them, NGOs should collaborate and foster linkages for optimal use of scarce resources to minimise duplication.

\section{Extension on Processing and Value Addition}

The survey showed relatively limited agricultural extension attention given to processing; a situation likely to have obvious implications for the general levels of processing and value addition in Ghana.

TABLE 6

Constraint to Extension Delivery on Processing

\begin{tabular}{lcc}
\hline Constraints to Processing & Frequency & Percentage \\
\hline Lack of machinery/equipment to demonstrate & 48 & 60.0 \\
Limited knowledge/Technical know-how & 13 & 16.3 \\
Financial constraints/credit to procure equipment & 8 & 10.0 \\
Lack of source of raw materials & 5 & 6.3 \\
High cost of processing equipment & 3 & 3.6 \\
Few Agricultural Extension Agents in processing & 2 & 2.5 \\
High cost of labour & 1 & 1.3 \\
Total & $\mathbf{8 0}$ & $\mathbf{1 0 0 . 0}$ \\
\hline
\end{tabular}


The limited extension attention to processing was largely attributed to the lack of relevant processing machinery or equipment, which had made the demonstration of processing methods virtually impossible. Besides, agricultural extension agents lacked the technical know-how to be able to extend processing technologies to farmers. Each Metropolitan, Municipal and District assemble was expected to have a District Women in Agricultural Development (WIAD) Officer with the responsibility for extending processing technologies to farmers; however, in view of lack of staff, most assemblies were without their respective WAID Officers.

Although processing of agricultural produce was observed to be informed by the geographical location, cassava processing into gari, cassava dough and cassava powder popularly known as kokonte, remained the leading activity in most of the localities, with as many as $50 \%$ of the respondents citing the processing of the commodity in their assemblies. This underlines the strategic role of cassava and its implications for job creation among the youth.

TABLE 7

Level of processing of commodities

\begin{tabular}{lcc}
\hline Commodity & Frequency & Percentage \\
\hline Cassava & 40 & 50.0 \\
Rice & 17 & 21.3 \\
Maize & 8 & 10.0 \\
Soybean & 4 & 5.0 \\
Groundnut & 3 & 3.8 \\
Fish & 2 & 2.5 \\
Sorghum & 2 & 2.5 \\
Shea nut & 1 & 1.3 \\
Sweet potato & 1 & 1.3 \\
Oil palm & 1 & 1.3 \\
Fruits & 1 & 1.3 \\
Total & $\mathbf{8 0}$ & $\mathbf{1 0 0 . 0}$ \\
\hline
\end{tabular}

Source: Fieldwork 2018

Although oil palm remained a popular commodity in southern Ghana, few farmers were engaged in the processing of the commodity. Farmers rather sold the raw materials to commercial mills that processed them into palm oil and other value-added products. Processing of groundnut, soybean, sweet potato and maize into value-added products, though appeared to be catching on, such processing was observed to be carried out on small and non-commercial scale. About eight out of every 10 respondents claimed extension messages on processing in their localities were delivered by the WIAD, the Directorate with the mandate for disseminating processing technologies. WAID's efforts, as shown in figure 5 , had been complemented by some agricultural NGOs, which could also be credited for their contribution in extension delivery on processing. Universities and research institutions as well as farmer groups however obtained marginal figures. This is an indication that departments and divisions with the mandate for research into value addition at universities and research institutions ought to deepen their extension activities to reach out to more communities with processing technologies arising out of their research.

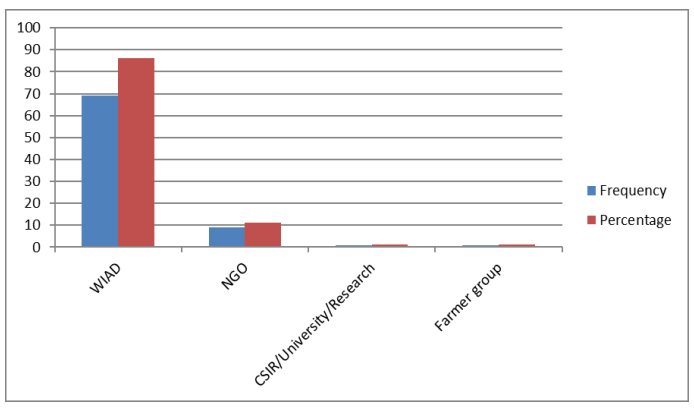

Fig. 5: Source of Extension Information on Processing Source: Fieldwork 2018

It is instructive to note the role of Farmerbased organisations (FBOs) in extending processing technologies, in spite of their rather 
poor showing in figure 5. Salifu et al. (2012) reported in a study that FBOs which engaged in processing and marketing activities tended to operate more like a business and were driven by revenue generation. This, according to them, had made FBOs more successful in attracting loans. Besides, FBOs were noted to give farmers bargaining power in the market place, enable cost-effective delivery of extension services and empower their members to influence policies that affect their livelihoods (Keefe \& Kalavalli, 2012).

Table 8 indicated that the activities of WIAD cut across all the 10 regions of Ghana with their presence felt more effectively in the Western and Eastern Regions of Ghana. A chi-square test conducted to establish a clearer picture across the 10 administrative regions of Ghana did not show any statistical significance.

TABLE 8

Activities of Extension Organisations Delivering Extension on Processing in the 10 regions

\begin{tabular}{|c|c|c|c|c|c|c|c|c|c|c|}
\hline \multicolumn{11}{|c|}{ Source of information } \\
\hline Region & WIAD & & $G O$ & & $C S I R / L$ & RES & Farme & & other & \\
\hline & Freq. & $\%$ & Freq. & $\%$ & Freq. & $\%$ & Freq. & $\%$ & Freq. & $\%$ \\
\hline Upper East & 8 & 11.6 & 0 & 0.0 & 0 & 0.0 & 0 & 0.0 & 0 & 0.0 \\
\hline Upper West & 5 & 7.2 & 0 & 0.0 & 0 & 0.0 & 0 & 0.0 & 0 & 0.0 \\
\hline Northern & 8 & 11.6 & 0 & 0.0 & 0 & 0.0 & 0 & 0.0 & 0 & 0.0 \\
\hline Brong Ahafo & 5 & 7.2 & 1 & 20.0 & 1 & 0.0 & 0 & 0.0 & 2 & 50.0 \\
\hline Ashanti & 5 & 7.2 & 1 & 20.0 & 1 & 100.0 & 0 & 0.0 & 0 & 0.0 \\
\hline Western & 9 & 13.0 & 0 & 0.0 & 0 & 0.0 & 0 & 0.0 & 0 & 0.0 \\
\hline Central & 7 & 10.1 & 1 & 20.0 & 0 & 0.0 & 1 & 100.0 & 0 & 0.0 \\
\hline Eastern & 9 & 13.0 & 0 & 0.0 & 0 & 0.0 & 0 & 0.0 & 1 & 25.0 \\
\hline Volta Region & 6 & 8.7 & 2 & 40.0 & 0 & 0.0 & 0 & 0.0 & 1 & 25.0 \\
\hline Greater Accra & 7 & 10.1 & 0 & 0.0 & 0 & 0.0 & 0 & 0.0 & 1 & 25.0 \\
\hline Value & & 39.450 & & & & & & & & \\
\hline Df & & 36 & & & & & & & & \\
\hline Sig. & & 0.318 & & & & & & & & \\
\hline
\end{tabular}

Source: Fieldwork 2018

\section{Extension on Marketing}

The study showed relatively limited extension delivery with regard to marketing as most farmers made their own marketing arrangements to sell their produce. However, delivery of extension messages on marketing found wider expression in extension agents linking farmers to potential buyers such as educational institutions. The Department of Agriculture occasionally places market information on the radio for the information of farmers and other agribusiness actors. These findings confirmed those of Altalb and Filipek (2016) who in a study on agricultural extension with regard to marketing in Poland and Iraq identified forms of extension on marketing to include assisting farmers to get organised as a group; making market information available; approaching the private sector to assist in solving transport problems; helping establish strategic partnerships between and among farmers and encouraging communication between farmers and sellers. 
TABLE 9

Nature of Extension on Marketing

\begin{tabular}{lcc}
\hline Type of extension & Frequency & Percentage \\
\hline Linkage to potential buyers (educational institutions) & 33 & 41.3 \\
Market information on radio & 18 & 22.5 \\
Information sharing on market and prices & 13 & 16.3 \\
Formation of District value chain committees & 11 & 13.8 \\
Facilitate in negotiation for good prices of products & 5 & 6.3 \\
Total & $\mathbf{8 0}$ & $\mathbf{1 0 0 . 0}$ \\
\hline
\end{tabular}

Source: Fieldwork 2018

Face-to-face interactions remained the most frequently used channel for communicating marketing information with $40 \%$ of respondents claiming to have used such channels for extension on marketing. This may not come as a surprise as synchronically interpersonal means of communication may be more comfortable with farmers perhaps on account of the fact that such means may generate more trust and confidence among participating parties. Additionally, the use of radio and farmerbased organisations were cited as other popular means of delivering extension on marketing.

\section{Extension on Input Supplying}

Although input supplying remained the least cited aspect of the value chain given extension attention, AEAs assisted farmers in the acquisition of inputs by linking them

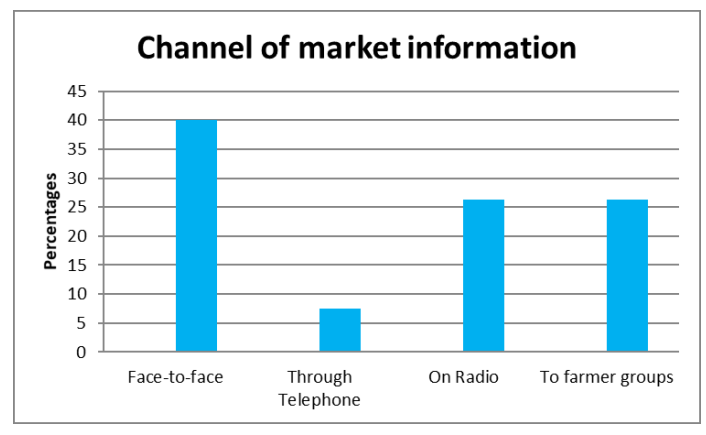

Fig. 6: Channels of market information to farmers Source: Fieldwork 2018

to private input dealers or the government Fertiliser Subsidy Programme, giving advice to farmers on quality or access and assisting farmers to get financial assistance.

TABLE 10

Nature of assistance given to farmers

\begin{tabular}{lcc}
\hline Nature of assistance & Frequency & Percentage \\
\hline Link/direct them to input dealers & 47 & 58.8 \\
Advice or information to farmers on quality/access & 18 & 22.5 \\
Through the government Fertiliser Subsidy Programme & 11 & 13.8 \\
Assisting farmers to get financial assistance & 4 & 5.0 \\
Total & $\mathbf{8 0}$ & $\mathbf{1 0 0 . 0}$ \\
\hline
\end{tabular}

Source: Fieldwork 2018 
Activities of commodity value chains are driven largely by private sector actors. This situation found wider expression with respect to extension delivery on input supplying, Private sector actors such as input dealers, play a critical role in driving activities in the value chain especially as it relates to value chain upgrading. The activities of these private sector actors according to Trienekens (2011) become relevant through ready access to information that supported product and process innovations linked to market requirements and the streamlining of the value chain through better communication, planning and provision of communication means. Ruben et al. (2007) and Gibbon (2001) further noted that private sector actors helped in setting up horizontal governance mechanisms that improved the power balance in the value chain and enhanced the bargaining position of small producers as well as in the setting up vertical governance mechanisms that facilitate a smooth flow of product and better distribution of value addition. While value chains may largely be driven by both private and public sector actors, the role of the latter may be facilitatory providing the enabling environment.

State institutions, according to Trienekens (2011), can provide the necessary pieces of legislation and support knowledge infrastructure development by setting up wellfunctioning education systems and providing training facilities. Additionally, they may be useful in giving access for value chain actors to production technology and other resources through for example import subsidies and provide access to credit (Trienekens, 2011). The partnerships between public and private sector actors in the provision of extension information may thus hold the key to driving activities of value chains and in effective value chain upgrading. Collectively, they have a role to play in pushing the agenda for a pluralistic extension system that responds effectively to the myriad of problems hindering the growth of value chains. However, a special case can be made for private sector actors given the unique role they play in value chain upgrading. Manteaw et al. (2015) in a comparative study of the pineapple and cocoa value chains concluded that a gradual reduction in public sector participation in value chain functions and support services and a steady expansion of the space for the participation of private sector actors such as processors and input suppliers may hold the key to building the capacity of actors to show more evidence of innovativeness to become more competitive. The more involvement of such private sector actors, the more likely the platform for more interactive learning towards systems innovation (Manteaw et al., 2015).

While both public and private sector actors have unique contributions to play in promoting agricultural extension delivery, Gwary, Asindaya and Abba (2016) proposed a model that finds expression in private sector investment and capacity development through Public-Private Partnership (PPP) arrangements; sustainability of private sector participation in extension through new staff orientation and training and the need for a sound legal, regulatory and institutional PPP framework. In support of this model, the FAO (2016) further advocates the need for public skills and institutions required to enable more effective partnerships with the private sector and the circumstances under which PPPs are likely to be the best modality for achieving sustainable development outcomes. 


\section{Conclusion}

Extension delivery along the commodity value chain ought to show some degree of balance to introduce the needed level of competitiveness in activities of the value chain. However, the study showed that extension delivery was exclusively directed at production; a situation that had influenced the quality of attention given to processing, marketing and input supplying. Extension on input supplying was observed to be a private sector-driven activity in the hands of input dealers. Consequently, extension on input supplying featured rather poorly in the public extension delivery landscape. The limited extension attention to processing was attributed to the lack of relevant processing machinery or equipment, which had made the demonstration of processing methods virtually impossible. The study also showed a relatively limited extension delivery with regard to marketing as most farmers made their own marketing arrangements to sell their produce. The role of Farmer-based Organisations in this endeavour is worth noting. This paper makes a strong case for extension policy that ensures a sense of balance and one that introduces competitiveness in value chain activities. This balance can be better achieved through a model that opens up space for effective Public-Private Partnership, which this paper believes may hold the key in making agricultural extension delivery more demand-driven and pluralistic. There is thus the need for a policy that is directed at sustainably building the capacity of agricultural extension agents to facilitate the balanced delivery of extension messages along the value chain that serves as a point of departure for this paper.

\section{REFERENCES}

Altalb, A. A. T. \& Filipek, T. C. (2016) The study of agricultural marketing extension in Poland and Iraq. Proceeding of $18^{\text {th }}$ IASTEM International Conference, Berlin, Germany, March 2016.

Ammani, A. A. \& Abdullahi, Y.M. (2015) Developing agricultural value chains: implications for agricultural extension. Advance in Agriculture and Biology 4 (4), 132 - 134.

Asiedu-Darko, E. (2013) Agricultural extension delivery in Ghana: A case study of factors affecting it in Ashanti, Eastern and Northern regions of Ghana, Journal of Agricultural Extension and Rural Development 5 (2), 37 -41 .

Asumugha, G. N., Njoku, M.E., Okoye, B.C., Amiedu, O.C., Ogbonna, M.C. \& Nwosu, K. I. (2009) Demand function and elasticity's for seed yam in Northern Nigeria. Nigeria Agricultural Journal 40 (1), 1 - 8.

Blum, M. L., Cofini, F., Sulaiman, R. V. (2020) Agricultural extension in transition worldwide: Policies and strategies for reform, Rome, FAO, https://doi.org/10.4060/ca8199

Campbell, R, Schiff H. \& Snodgrass, D. (2009) Global food security response: West Africa Rice Value Chain Analysis. Micro Report 161.

Danso-Abbeam, G., Ehiakpor, D. S. \& Aidoo, R. (2018) Agricultural extension and its effects on farm productivity and income: Insights from Northern Ghana. Agriculture and Food Security 7, Article Number: 74 (2018)

Dimelu, M. U., Salua, E. S., \& Igbokwe, E. M. (2013) Performance of Faith-based grassroot Non-governmental Organisations in rural development in Nasarawa State, Nigeria. Academic Journals International NGO Journal 8 (7), 146-152. 
FAO (2019) Developing sustainable value chains for small-scale livestock producers. Edited by G. Leroy \& M. Fernando, FAO Animal Production and Health Guidelines, No. 21, Rome

FAO (2016) Public-Private Partnership for agribusiness development- $A$ review of international experiences, Rome, Italy. FAO.

Farrington, J., Christoplos, L, Kidd, A. \& Beckman, M. (2002) Extension, poverty and vulnerability: The scope for policy reform: Final Report of a Study for the Neuchatel Initiative, Working Paper 155. Overseas Development Institute ODI: London.

Gêmo, H.C., Eicher, K. \& Teclemariam, S. (2005) Mozambique's experience in building a national extension system. East Lansing, MI: Michigan State University Press.

Gibbon, P. (2001) Upgrading primary production: A Global commodity chain approach. World Development 29 (2), 345 - 363.

Glendenning, C. J., S. Babu, \& Asenso-Okyere, K. (2010) Review of agricultural extension in India, are farmers information needs being met? International Food Policy Research Institute, Eastern and Southern Africa Regional Office.

Gwary, M. M., Asidaya, Z. \& Abba, A. M. (2016) Public-Private Partnership as panacea for effective extension delivery: Review of experience and potential in Nigeria, Journal of Agricultural Science 4 (3), 50 - 55.

Henriksen, L., Riisgaard L., Ponte S., Hartwich F. \& Kormawa, P. (2010) Agro-Food value chain Interventions in Asia: A review and analysis of case studies. Working Paper. UNIDO. Retrieved October 24, 2016. https://www.unido.org/sites/ default/files/2011-01/WorkingPaper VC AsiaFinal 0.pdf

Joshi, S. K. (2015) Conceptual paper on value chain financing: A vital tool for farm to market linkage in agribusiness. International Journal of Commerce and Business Management 8 (2), $286-289$.

Kaplinsky, R. \& Morris, M. (2000) A handbook for value chain analysis. IDRC. Retrieved October 24, 2016. http://www.fao.org/fileadmin/ userupload/fisheries/docs/ValueChain Handbool.pdf

Kazeem, A. A., Dare, A., Olalekan, O., Abiodun, S. E. \& Komolafe, T. L. (2017) Attitudes of farmers to extension training in Nigeria: Implications for adoption of improved agricultural technologies in Ogun State, Southwest Region. Journal of Agricultural Sciences 62 (4), 423 - 443.

Meyer-Stamer, J. (2004) Regional value chain initiatives: An opportunity for the application of the PACA-Approach. Mesopartner working paper. Mesopartner: Duisburg.

Manteaw, S.A., Anaglo, J.N. \& Boateng, S.D. (2015) The dynamics of linkages and innovativeness in publicly and privately driven agricultural value chains. Journal of Agricultural Extension 19 (1), $1-23$.

Manteaw, S. A., Sakyi-Dawson, O., Atengdem, P. B., Sarpong, D. B., \& Aligebam, B. B. (2014) Triggers of innovativeness in publicly and privately driven agricultural value Chains: Case study of cocoa and pineapple in Ghana, International Journal of Development and Sustainability 3 (5), 1026 - 1042.

Mmbengwa, V. M., M. Gundidza, J. A. Groenewald \& Van Schalkwyk, H. D. (2009) Factors affecting extension workers in their rendering of effective service to pre and post settled farmers in Government-Initiated and Supported Farming Small, Micro and Medium Enterprises. South African Journal of Agricultural Extension 38, $1-14$.

Nguyen, T. B. T. (2016) Reliability statistics for relationship the state factor and the added value chain of the aquaculture enterprises in Vietnam. European Journal of Business and Social Sciences 5 (4), 85 - 97. 
Oluwasusu, J. O. \& Akanni, Y. O. (2014) Effectiveness of Extension Services Among Food Crop Farmers in Ekiti State, Nigeria, Journal of Agricultural \& Food Information 15 (4).

Owens, T., Hoddinott, J., Kinsey, B. (2003) The impact of agricultural extension on farm production in resettlement areas of Zimbabwe, Economic Development and Cultural Change 51 (2), 337 - 357.

Porter, M. E. (1998) Competitive advantage: creating and sustaining superior performance; with a new introduction. New York: Free Press.

Rivera, W. M. \& Qamar, M. K. (2003) Agricultural extension, rural development and the food security challenge. FAO: Rome.

Ruben, R., M. van Boekel, A. van Tilburg \& Trienekens, J. (eds). (2007) Governance for quality in tropical food chains, The Netherlands: Wageningen Academic Publishers

Saleh, J. M., Man, N., Lafta, A. H., Saleh, M. H., Nassam, S., Nawi, N. M. \& Kshash, B. H. (2016) A Review: Training Requirements of Agriculture Extension Officers in Iraq. Asian Journal of Applied Sciences 9 (2), $34-40$

Salifu, A., Funk Lee, R., Keefe, M. \& Kalavalli, S. (2012) Ghana strategy support programme. International Food Policy Research Institute. Working Paper 31.

Sattaka, P., Pattaratuma, S., \& Attawipakpaisan, G. (2017) Agricultural extension services to foster production sustainability for food and cultural security of glutinous rice farmers in Vietnam, Kasetsart. Journal of Social Sciences 38, 74 80.
Shepherd, A.W. (2007) Approaches to Linking Producers to Markets: A Review of Experiences to Date. FAO: Rome.

Sinkaiye, T. (2005) Agricultural extension participating methodologies and approaches in agricultural extension in Nigeria, In Afolayan, S.F. (Ed) Ilorin AESON: 220 -233.

Sulaiman, V.R. \& Hall, A.J. (2002) Beyond technology dissemination: reinventing agricultural extension, Outlook on Agriculture 31 (4), $225-233$.

Swanson, B.E. (2009) Changing extension paradigms within a rapidly changing global economy. Proceedings of the 19th European Seminar on Extension Education. Assisi, Italy. (http://www. agraria.unipg.it/). Assessed 24, March. (2018)

Swanson, B. E. (2008) Global Review of Good Agricultural Extension and Advisory Service Practices. Research and Extension Division, Natural Resources Management.

Trienekens, J. H. (2011) Agricultural value chains in developing countries. A framework for analysis, International Food and Agribusiness Management Review 14 (2), 51 - 82.

USAID (2004) Agricultural Partnerships for Productivity and Prosperity. $\left(\mathrm{AP}^{3}\right)$. USAID: Washington, DC.

USAID (2014) Strengthening pluralistic agricultural extension in Ghana. Report on the MEAS Rapid Scoping Mission Field Work conducted from October $1^{\text {th }}$ to November $7^{\text {th }} 2012$.

Webber, C. M, \& Labaste P. (2009) Building competitiveness in Africa's agriculture: A guide to value chain concepts and applications. The International Bank for Reconstruction and Development. The World Bank, Washington, DC. 